\title{
Clinical Features, DYT1 Mutation Screening and Genotype-Phenotype Correlation in Patients with Dystonia from Iran
}

\author{
Mohammad Taghi Akbari ${ }^{a} \quad$ Zahra Zand $^{\mathrm{b}}$ Gholam Ali Shahidic \\ Mohammad Hamid ${ }^{b}$ \\ ${ }^{a}$ Department of Medical Genetics, Faculty of Medical Sciences, Tarbiat Modares University, ${ }^{b}$ Molecular Medicine \\ Division, Biotechnology Research Center, Pasteur Institute of Iran, and 'Department of Neurology, Iran University \\ of Medical Sciences, Hazrat Rasool Hospital, Tehran, Iran
}

\section{Key Words}

Primary dystonia $\cdot$ Clinical features · DYT1 gene · GAG deletion

\section{Abstract \\ Objective: To test Iranian patients with primary torsion dys- tonia to determine the frequency of 904-906 del GAG muta- tion in the DYT1 (TOR1A) gene and to investigate the geno- type-phenotype association for this disease. Subjects and Methods: Sixty-three patients with primary dystonia were investigated. DNA was extracted from peripheral blood and these samples were subjected to PCR-sequencing for exon 5 of the DYT1 gene. Results: Of the 63 patients, 10 (15.9\%) car- ried the triplet GAG deletion mutation; this is a high DYT1- positive rate in comparison with other populations and the type of dystonia in this positive group was generalized in all except 1. In our patients, limbs were the most severely in- volved site at the time of onset and in most cases it devel- oped to generalized form. The majority of DYT1-positive cas- es showed higher leg onset (5 patients, 62.5\%) in comparison with higher arm onset in negative patients (20 patients, $50 \%)$. Also, the progression to generalized dystonia in DYT1-}

positive patients was significantly higher than in DYT1-negative patients. The mean age at onset was $8.6 \pm 1.6$ years (7-12 years) in DYT1-positive patients, while mean age at onset in patients with no GAG deletion mutation was higher (15.7 \pm 11.5 years). Conclusions: The DYT1 904-906 del GAG mutation is responsible for some of Iranian dystonia patients, and screening for the DYT1 deletion is significant in cases with the generalized type of primary dystonia. Also, patients with leg or arm onset at a younger age are more likely to be DYT1-positive among primary torsion dystonia cases.

Copyright $\odot 2012$ S. Karger AG, Basel

\section{Introduction}

Dystonia is a group of movement disorders that are characterized by sustained muscle contractions causing twisting, repetitive movements or abnormal postures, affecting one or more sites of the body [1]. Dystonia is classified as either primary or secondary. Among primary dystonias, DYT1 dystonia manifests autosomal dominant inheritance with low penetrance $(30-40 \%)$ and is

\section{KARGER}

Fax +41 613061234

E-Mail karger@karger.ch

www.karger.com
(C) 2012 S. Karger AG, Basel

1011-7571/12/0215-0462\$38.00/0

Accessible online at:

www.karger.com/mpp
Mohammad Hamid

Molecular Medicine Division

Biotechnology Research Center, Pasteur Institute of Iran

Tehran 13164 (Iran)

Tel. +98 21669533 1120, E-Mail hamid143@yahoo.com 
Fig. 1. Comparison of a DYT1-positive patient's DNA with the normal sequence.

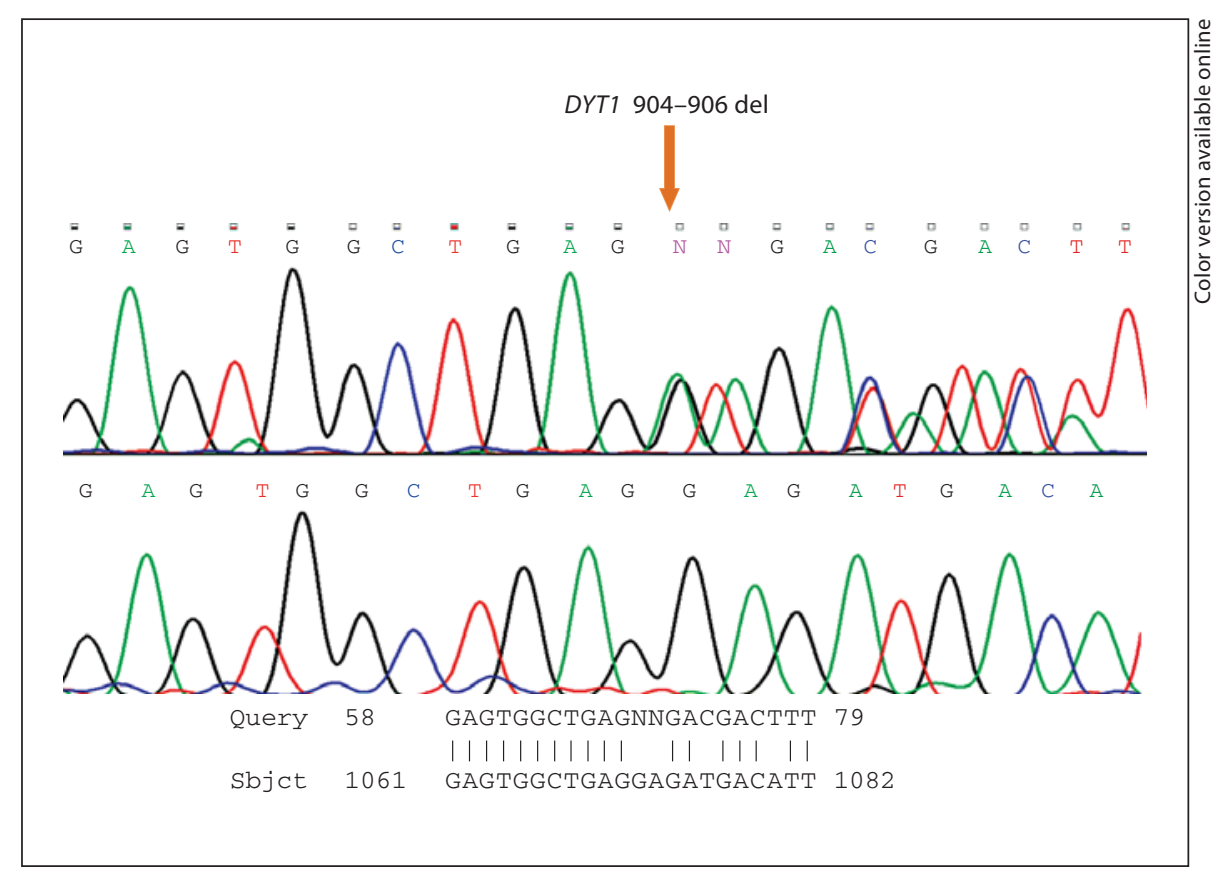

usually the only symptom of the disease [2]. It is caused by a mutation in the DYT1 (also termed TOR1A) gene (9q34), which mainly leads to a 3-bp deletion (GAG) in exon 5 and subsequently results in loss of a glutamic acid residue in the protein torsin A $[3,4]$. Primary dystonia is also termed primary torsion dystonia (PTD), and its onset typically is either during childhood (early onset around the age of 9 years) or in rare cases during adulthood (late onset at 45 years). Usually, disease onset is before the age of 26 years $[1,2]$. In the secondary forms, dystonia is usually caused by an underlying disease which can be either genetic or environmental [5-7].

Dystonia can also be classified into different subtypes according to the part of the body affected: focal (affecting one body part, such as neck or leg), segmental (affecting two adjacent areas like head and neck), multifocal (two nonadjacent areas are involved, such as two arms), hemidystonia (when it is confined to one side of the body) and generalized $[8,9]$. Most of PTDs begin with involvement of a limb in childhood with gradual progression to the generalized form [6].

The purpose of this study was to determine the rate of DYT1 mutation in a consecutive series of Iranian patients with PTD, and to investigate the association of this mutation with phenotypic characteristics of dystonia, which are highly variable.

\section{Subjects and Methods}

Seventy-two unselected non-Jewish dystonia patients (42 males, 30 females) were examined by three neurologist physicians over 4 years; 9 were described as secondary dystonia patients due to birth incidents, limb injuries, an underlying disease or infection, or side effects of drugs $[9,10]$, and these patients were excluded from this study. The Ethics Committee of the Pasteur Institute of Iran approved this study. Following written informed consent for genetic studies from the remaining 63 patients, $10 \mathrm{ml}$ peripheral blood was taken from each individual, collected in EDTA tubes and kept at $-20^{\circ} \mathrm{C}$. Whole-blood DNA extraction was carried out by standard method of salting out. Amplification of exon 5 of the TOR1A gene was performed by PCR using forward and reverse primers (DYT1F 5'-CCTGGAATACAAACACCTA3', DYT1R 5'-GGCTGCCAATCATGACTGTC-3'). The PCR conditions for amplification of exon 5 of the TOR1A gene are as follows: one cycle at $94^{\circ} \mathrm{C}$ for $5 \mathrm{~min}, 94^{\circ} \mathrm{C}$ for $1 \mathrm{~min}, 60^{\circ} \mathrm{C}$ for $1 \mathrm{~min}$, $72^{\circ} \mathrm{C}$ for $1 \mathrm{~min}$ in 32 cycles, and finally one cycle at $72^{\circ} \mathrm{C}$ for $5 \mathrm{~min}$. Then sequencing was performed using ABI XL Sequencer (Applied Biosystems, Foster City, Calif., USA) as described elsewhere [11].

For statistical analysis, quantitative variables were expressed as means $\pm \mathrm{SD}$ while qualitative variables were expressed as percentages.

\section{Results}

Ten cases out of 63 PTD patients (15.9\%) were positive for GAG deletion in DYT1 (TOR1A). The electrophoresis of a DYT1-positive patient in comparison with the normal 
Table 1. Patients with positive DYT1 mutation

\begin{tabular}{|c|c|c|c|c|c|c|}
\hline $\begin{array}{l}\text { No./ } \\
\text { sex }\end{array}$ & $\begin{array}{l}\text { AAE, } \\
\text { years }\end{array}$ & $\begin{array}{l}\mathrm{AAO}, \\
\text { years }\end{array}$ & $\begin{array}{l}\text { Onset } \\
\text { localization }\end{array}$ & $\begin{array}{l}\text { Type of } \\
\text { dystonia }\end{array}$ & Family history & Disease progression \\
\hline $1 / \mathrm{M}$ & 16 & 12 & R leg & generalized & negative & $\mathrm{R}$ leg, $\mathrm{R}$ hand, whole body \\
\hline $3 / \mathrm{M}$ & 9 & $\mathrm{NA}^{5}$ & NA & NA & NA & NA \\
\hline $4 / \mathrm{M}$ & 16 & 8 & R leg & focal & negative & R leg \\
\hline $5 / F$ & 34 & 9 & R leg & generalized & negative & $\mathrm{R}$ foot, $\mathrm{R}$ leg, waist, $\mathrm{R}$ hand, $\mathrm{L}$ foot \\
\hline $7 / \mathrm{F}$ & 13 & NA & NA & NA & NA & NA \\
\hline $8 / \mathrm{M}$ & 11 & 9 & $\mathrm{R}$ toes & generalized & positive ( 2 nd cousin) & $\mathrm{R}$ toes, $\mathrm{R}$ leg, trunk, $\mathrm{R}$ hand \\
\hline $9 / \mathrm{M}$ & 8 & 7 & waist & generalized & positive ( 2 nd cousin) & waist, legs, neck \\
\hline $10 / \mathrm{F}$ & 9 & 7 & $\mathrm{R}$ leg & generalized & negative & $\mathrm{R}$ foot, $\mathrm{R}$ leg, trunk, L leg \\
\hline
\end{tabular}

$\mathrm{AAE}=$ Age at examination; $\mathrm{AAO}=$ age at onset; $\mathrm{R}=$ right $\mathrm{L}=$ left $; \mathrm{NA}=$ not available.

Table 2. Site of onset and types of dystonia in PTD patients, compared with DYT1 mutation-negative and -positive status

\begin{tabular}{|c|c|c|c|c|c|c|}
\hline & \multicolumn{2}{|c|}{ Available PTD patients } & \multicolumn{2}{|c|}{ Negative patients } & \multicolumn{2}{|c|}{ Positive patients } \\
\hline \multicolumn{7}{|l|}{ Site of onset } \\
\hline Foot, leg & $12(6: 6)$ & 25.00 & $7(3: 4)$ & 17.5 & $5(3: 2)$ & 62.5 \\
\hline Hand, arm & $22(12: 10)$ & 45.83 & $20(12: 8)$ & 50.0 & $2(0: 2)$ & 25.0 \\
\hline Neck & $3(1: 2)$ & 6.25 & $3(1: 2)$ & 7.5 & 0 & 0 \\
\hline Multiple sites & $2(1: 1)$ & 4.17 & $2(1: 1)$ & 5.0 & 0 & 0 \\
\hline \multicolumn{7}{|l|}{ Types of dystonia } \\
\hline Focal & $8(5: 3)$ & 16.67 & $7(4: 3)$ & 17.5 & $1(1: 0)$ & 12.5 \\
\hline Segmental & $7(3: 4)$ & 14.58 & $7(3: 4)$ & 17.5 & 0 & 0 \\
\hline Multifocal & $6(3: 3)$ & 12.50 & $6(3: 3)$ & 15.0 & 0 & 0 \\
\hline Hemidystonia & $3(1: 2)$ & 6.25 & $3(1: 2)$ & 7.5 & 0 & 0 \\
\hline
\end{tabular}

$\mathrm{M}: \mathrm{F}=$ Male:female ratio

sequence is shown in figure 1 . Clinical data were available for $48(76.2 \%)$ of the 63 primary dystonia patients. In the DYT1-positive cohort, clinical data were available for 8 $(80 \%)$ of the patients, and in the DYT1-negative cohort, clinical data were available for 40 (75.5\%) (table 1).

The mean age of the DYT1-positive cohort, negative cohort and all available $(\mathrm{n}=48)$ patients was $15.1 \pm 8.4$ (range 8-34), $22.3 \pm 10.8$ (range 6-54), and $21.1 \pm 10.8$ years (range 6-54), respectively. Almost all of these 48 patients were unrelated cases, except 2 (table 1), who were second cousins. Among the positive patients, 3 had positive family history and all but 1 patient had the generalized type of dystonia; mean age at onset was $8.6 \pm 1.6$ years (table 1), while mean age at onset in DYT1 mutationnegative patients was higher (15.7 \pm 11.5 years).

In all PTD patients, limbs were the most severely involved sites at the time of onset: hand and arm 45.83\%; foot and leg $25 \%$, and in most cases it had developed to the generalized form (50\%). The difference between sites of onset in the majority of DYT1-positive cases in com- 
Table 3. Types of dystonia in DYT1-positive and -negative patients with regard to their site of onset

\begin{tabular}{|c|c|c|c|c|c|c|}
\hline \multirow[t]{2}{*}{ Site of onset } & \multicolumn{5}{|c|}{ Type of dystonia } & \multirow[t]{2}{*}{ Total } \\
\hline & focal & segmental & multifocal & hemidystonia & generalized & \\
\hline Hand, arm & $4(\mathrm{~N})$ & $3(\mathrm{~N})$ & $3(\mathrm{~N})$ & $1(\mathrm{~N})$ & $11(9 \mathrm{~N}, 2 \mathrm{P})$ & $22(20 \mathrm{~N}, 2 \mathrm{P})$ \\
\hline Neck & $2(\mathrm{~N})$ & $1(\mathrm{~N})$ & 0 & 0 & 0 & $3(\mathrm{~N})$ \\
\hline Cranial & $1(\mathrm{~N})$ & $2(\mathrm{~N})$ & 0 & 0 & $2(\mathrm{~N})$ & $5(\mathrm{~N})$ \\
\hline Total & $8(7 \mathrm{~N}, 1 \mathrm{P})$ & $7(\mathrm{~N})$ & $6(\mathrm{~N})$ & $3(\mathrm{~N})$ & $24(17 \mathrm{~N}, 7 \mathrm{P})$ & $48(40 \mathrm{~N}, 8 \mathrm{P})$ \\
\hline
\end{tabular}

$\mathrm{P}=$ Positive patient(s); $\mathrm{N}=$ negative patient(s).

parison with negative patients was an outstanding result, which showed higher arm onset in DYT1-negative (50\%) in contrast to higher leg onset in positive $(62.5 \%)$ patients. Also, the progression to the generalized form of dystonia in DYT1-positive patients was significantly higher $(\mathrm{p}=$ $0.047)$ than in DYT1-negative patients $(87.5 \%$ in DYT1positives and $42.5 \%$ in DYT1-negatives). These data are summarized in table 2 , and there are data about the latest type of dystonia - at the time of writing the article - in all available patients with regard to their sites of onset in table 3. In addition, in these 48 available patients, females had earlier onset of dystonia (12 \pm 5.5$)$ compared with males (15 \pm 13$)$, and except for those 3 positive patients none of them had a positive family history (table 1). We also had a rare finding: a late-onset negative patient with leg onset at the age of 48 whose disease had progressed to the generalized form within 6 years of onset (involving limbs, trunk, neck and face).

\section{Discussion}

Dystonia is a severe disease in most cases. Although primary dystonia is infrequent in the general population, it affects all aspects of a patient's life. Considering the fact that Jewish communities are closed with regard to marriage with non-Jewish populations, the likelihood of admixture with the Iranian population is very remote. To the best of our knowledge there has been no previous report about its clinical features, mutation screening, or genotype-phenotype correlation amongst people of Iran or neighboring countries prior to this report. We reported 63 Iranian non-Jewish patients with primary dystonia with a high frequency of DYT1 mutation, comparing with other populations [12-25].

In this study, mean age at onset of DYT1 mutationpositive and DYT1 mutation-negative patients was $8.6 \pm$ 1.6 and $15.7 \pm 11.5$, respectively. In comparison with some previous data, we had earlier age at onset [12-14, 26]. However, our patients showed a later age at onset than Italians [15]. The data about age at onset in females and males (females $12 \pm 5.5$, males $15 \pm 13$ ) is also unlike most of previously published data, which showed earlier age at onset in males [16, 17, 27].

With regard to generalization rates $(87.5 \%$ in positive and $50 \%$ in overall PTD patients), while most of our patients had generalized form, most patients in other studies have been reported with focal dystonia $[17,26,28]$. It might be because of our patients' earlier age at onset, since according to some data, later onset age may protect the patient from disease progression [18]. Alternatively, some patients with focal or even segmental dystonias may not have sought proper treatment and remained undiagnosed.

The patient with onset at 48 years was remarkable due to having generalized dystonia, which more often occurs in early-onset patients $[12,29]$, although there were also 3 patients in a German study who presented with generalized dystonia with age at onset over 40 years [28].

Overall, as a result of this study and according to the guidelines of the European Federation of Neurological Societies [18], molecular testing for GAG deletion in the DYT1 gene is recommended in cases with early-onset primary dystonia regardless of family history, especially in those who suffer from the generalized type. 


\section{Conclusions}

The DYT1 904-906 del GAG mutation was responsible for the dystonia of some Iranian patients, and screening for the DYT1 deletion is important in cases with the generalized type of primary dystonia. Also, patients with leg or arm onset at a younger age were more likely to be DYT1-positive among primary torsion dystonia cases.

\section{Acknowledgments}

The authors appreciate the collaboration of patients and their neurologist physicians. The study has been supported by a grant from the Iran National Science Foundation (INSF), No. 89002245.

\section{References}

1 Fahn S, Marsden C, Calne D: Classification and investigation of dystonia. Mov Disord 1987;2:332.

$\checkmark 2$ Bressman SB, de Leon D, Brin MF, Risch N, Burke RE, Greene PE, Shale H, Fahn S: Idiopathic dystonia among Ashkenazi Jews: evidence for autosomal dominant inheritance. Ann Neurol 1989;26:612-620.

$\checkmark 3$ Goodchild RE, Dauer WT: The AAA+ protein torsin A interacts with a conserved domain present in LAP1 and a novel ER protein. J Cell Biol 2005;168:855-862.

$\checkmark 4$ Ozelius LJ, Hewett JW, Page CE, Bressman SB, Kramer PL, Shalish C, de Leon D, Brin MF, Raymond D, Corey DP, Fahn S, Risch NJ, Buckler AJ, Gusella JF, Breakefield XO: The early-onset torsion dystonia gene (DYT1) encodes an ATP-binding protein. Nat Genet 1997; 17:40-48.

$\checkmark 5$ Albanese A, Barnes MP, Bhatia KP, Fernandez-Alvarez E, Filippini G, Gasser T, Krauss JK, Newton A, Rektor I, Savoiardo M, Valls Solè J: A systematic review on the diagnosis and treatment of primary (idiopathic) dystonia and dystonia plus syndromes: report of an EFNS/MDS-ES Task Force. Eur J Neurol 2006; 13:433-444.

6 Fahn S, Bressman SB, Marsden CD: Classification of dystonia. Adv Neurol 1998;78:1-10.

$\checkmark 7$ Valente EM, Warner TT, Jarman PR, Mathen D, Fletcher NA, Marsden CD, Bhatia KP, Wood NW: The role of DYT1 in primary torsion dystonia in Europe. Brain 1998;121: 2335-2339.

$>8$ de Carvalho Aguiar PM, Ozelius LJ: Classification and genetics of dystonia. Lancet Neurol 2002;1:316-325.

9 http://www.wemove.org/dys/dys_anat.html.

$>10$ Schneider SA, Bhatia KP: Secondary dystonia - clinical clues and syndromic associations. Eur J Neurol 2010;17(suppl 1):52-57.

11 Al Hashem G, Al Sweih N, Rotimi VO: Sequence analysis of $b l a_{\mathrm{CTX}-\mathrm{M}}$ genes carried by clinically significant Escherichia coli isolates in Kuwait hospitals. Med Princ Pract 2011; 20:213-219.
12 Im JH, Ahn TB, Kim KB, Ko SB, Jeon BS: DYT1 mutation in Korean primary dystonia patients. Parkinsonism Relat Disord 2004; 10:421-423.

13 Lin YW, Chang HC, Chou YH, Chen RS, Hsu WC, Wu WS, Weng YH, Lu CS: DYT1 mutation in a cohort of Taiwanese primary dystonias. Parkinsonism Relat Disord 2006;12: 15-19.

14 Major T, Svetel M, Romac S, Kostic VS: DYT1 mutation in primary torsion dystonia in a Serbian population. J Neurol 2001;248:940 943.

15 Zorzi G, Garavaglia B, Invernizzi F, Girotti F, Soliveri P, Zeviani M, Angelini L, Nardocci N: Frequency of DYT1 mutation in early onset primary dystonia in Italian patients. Mov Disord 2002;17:407-408.

16 Jamora R, Tan A, Tan L: A 9-year review of dystonia from a movement disorders clinic in Singapore. Eur J Neurol 2006;13:77-81.

17 Naiya T, Biswas A, Neogi R, Datta S, Misra AK, Das SK, Ray K, Ray J: Clinical characterization and evaluation of DYT1 gene in Indian primary dystonia patients. Acta Neurol Scand 2006;114:210-215.

- 18 Harbo HF, Finsterer J, Baets J, Van Broeckhoven C, Di Donato S, Fontaine B, De Jonghe P, Lossos A, Lynch T, Mariotti C, Schöls L, Spinazzola A, Szolnoki Z, Tabrizi SJ, Tallaksen C, Zeviani M, Burgunder JM, Gasser T: EFNS guidelines on the molecular diagnosis of neurogenetic disorders: general issues, Huntington's disease, Parkinson's disease and dystonias. Eur J Neurol 2009;16:777-785.

19 Dhaenens CM, Krystkowiak P, Douay X, Charpentier P, Bele S, Destée A, Sablonnière B: Clinical and genetic evaluation in a French population presenting with primary focal dystonia. Mov Disord 2005;20:822-825.

20 Maniak S, Sieberer M, Hagenah J, Klein C, Vieregge P: Focal and segmental primary dystonia in north-western Germany - a clinico-genetic study. Acta Neurol Scand 2003; 107:228-232.
21 Kamm C, Naumann M, Mueller J, Mai N, Riedel L, Wissel J, Gasser T: The DYT1 GAG deletion is infrequent in sporadic and familial writer' s cramp. Mov Disord 2000;15: 1238-1241.

22 Kamm C, Castelon-Konkiewitz E, Naumann M, Heinen F, Brack M, Nebe A, CeballosBaumann A, Gasser T: GAG deletion in the DYT1 gene in early limb-onset idiopathic torsion dystonia in Germany. Mov Disord 1999;14:681-683.

23 Hjermind LE, Werdelin LM, Sorensen SA: Inherited and de novo mutations in sporadic cases of DYT1-dystonia. Eur J Hum Genet 2002;10:213-216.

24 Matsumoto S, Nishimura M, Kaji R, Sakamoto T, Mezaki T, Shimazu H, Murase N, Shibasaki H: DYT1 mutation in Japanese patients with primary torsion dystonia. Neuroreport 2001; 12:793-795.

-25 Zhang SS, Fang DF, Hu XH, Burgunder JM, Chen XP, Zhang YW, Shang HF: Clinical feature and DYT1 mutation screening in primary dystonia patients from south-west China. Eur J Neurol 2010;17:846-851.

26 Lebre AS, Durr A, Jedynak P, Ponsot G, Vidailhet M, Agid Y, Brice A: DYT1 mutation in French families with idiopathic torsion dystonia. Brain 1999;122:41-45.

27 Sex-related influences on the frequency and age of onset of primary dystonia. Epidemiologic Study of Dystonia in Europe (ESDA) Collaborative Group. Neurology 1999;53: 1871-1873.

28 Grundmann K, Laubis-Herrmann U, Bauer I, Dressler D, Vollmer-Haase J, Bauer P, Stuhrmann M, Schulte T, Schols L, Topka H, Riess O: Frequency and phenotypic variability of the gag deletion of the DYT1 gene in an unselected group of patients with dystonia. Arch Neurol 2003;60:1266-1270.

29 Szczaluba K, Jurek M, Milewski M, Friedman A, Kadziolka B, Szolna A, Bal J, Mazurczak T: Clinical characteristics of carriers of a GAG deletion in the DYT1 gene amongst Polish patients with primary dystonia. Eur J Neurol 2007;14:659-662. 